2016-07-30

Partnerships Work: Continuing the Success in Swimming and Water Safety

\author{
Lynch, TJ
}

http://hdl.handle.net/10026.1/6380

10.1007/978-3-319-31667-3_8

Springer International Publishing

All content in PEARL is protected by copyright law. Author manuscripts are made available in accordance with publisher policies. Please cite only the published version using the details provided on the item record or document. In the absence of an open licence (e.g. Creative Commons), permissions for further reuse of content should be sought from the publisher or author. 


\title{
Partnerships Work: Continuing the Success in Swimming and Water Safety
}

\begin{abstract}
The purpose of this chapter is to share the continued swimming education community partnership programme success. Pathways were investigated and initiated in 2011 which began a journey of collaboration between Australian Registered Training Organisations (RTO), the local health industry (local leisure and sports centre) and external swimming instructors employed at the venue, local primary schools, and the university sector; Monash University (Gippsland). The programme accentuated the vital role pre-service teacher education can play in the development of children's swimming and water safety knowledge, skills, and understanding within all communities, especially the socio-economically disadvantaged.
\end{abstract}

The purpose of this chapter is to share the continued swimming education community partnership programme success. As discussed, pathways were investigated and initiated in 2011 which began a journey of collaboration between Australian Registered Training Organisations (RTO), the local health industry (local leisure and sports centre) and external swimming instructors employed at the venue, local primary schools and the university sector; Monash University (Gippsland). The programme accentuated the vital role pre-service teacher education can play in the development of

(C) The Editor(s) (if applicable) and The Author(s) 2016

T. Lynch, The Future of Health, Wellbeing and Physical Education, DOI 10.1007/978-3-319-31667-3_8 
children's swimming and water safety knowledge, skills, and understanding within all communities, especially the socio-economically disadvantaged.

As has been stated throughout this storyline, the units (also referred to as modules in the UK) were offered biennially, that is, units were offered once every two years. The rational for the biennial design was to enable the Initial Teacher Education (ITE) students to cover as many units as possible within the context of having one PE lecturer, who was also the leader and pioneer of the 'Best Start' community partnership. Swimming lessons held in semester one, 2011 were embedded within unit EDF 2611 (Chap. 3). The next time this unit, and subsequently, the swimming lessons could be offered was in semester one, 2013.

\section{Actors}

\section{Leadership}

As it had been two years since the last time swimming lessons were conducted, the leader decided to make one major amendment, to take control of all liaising with schools. In 2011, it was collaboratively agreed that the leisure centre staff would use their established connections with the schools, which although plausible at the time, did prove to be difficult from a university perspective. Details of difficulties that resulted from this process are discussed in Chap. 10.

The leader was required to renew or keep updated qualifications for pathways to remain valid. Renewal of Life Saving Victoria endorsed Service Membership, enabled the pre-service teachers to complete their Bronze Medallion and Resuscitation. This involved the leader completing/updating a Bronze Medallion (accreditation valid for 12 months), a current level 2 First Aid award (accreditation valid for three years) and a current resuscitation award (cardiopulmonary resuscitation $[\mathrm{CPR}]$ —accreditation valid for 12 months). Endorsement of the resuscitation (RE) award was vital as it was a requirement for the ITE students (pre-service teachers) to receive their SAT swim instructor qualification (pathway within a pathway).

The leader needed to apply for an updated qualification as a SAT Course Presenter. This was essential for the ITE students to become swimming instructors in the unit pathway. As part of the application, the leader needed to evidence a current CPR, a recent working with children/ police check (this was evidenced by current teacher registration within the state of Victoria), swimming professional development undertaken in 
were established. Such suggestions were received encouragingly by the teachers and principals involved, and discussions disclosed that this may possibly involve some research.

Transparency was a key theme throughout all lessons within the 'Best Start' programme. Swimming lessons were conducted in a public Leisure Centre facility during the day, open for any interested parties to witness; swimming instructors, parents, leisure centre staff, university students, and community members. Further transparency was achieved in a paper presented and discussed at the '28th Australian Council for Health, Physical Education and Recreation (ACHPER) International Conference, Melbourne (Australia)' in November, 2013. The paper was also published in the conference proceedings. (Lynch 2013)

Communication of successes and drawbacks was also presented and discussed during the Teacher Education Research Group (TERG) programme of events, University of East London (UK), 15 January, 2014. The leader was kindly invited and the title of the presentation was 'Community education collaborations: Health and Physical Education (HPE)'. The presentation and data shared was warmly received by various educationalists and encouraging feedback was given to the leader. It was during this visit to the UK, which involved gathering further data from the ITE Ofsted 'outstanding' PE primary programme, where problems with implementing swimming in English primary schools were revealed to the leader. Media reports about schools not meeting curriculum requirements were bountiful in British media reports. Such reports were encouraging for the leader at the time. They assisted him to realise the power of community in addressing this issue of swimming impediments for children and inspired him to continue with his efforts.

\section{REFERENCES}

Australian Government. (2011). Review of funding for schooling, final report. Retrieved from https://docs.education.gov.au/system/files/doc/other/ review-of-funding-for-schooling-final-report-dec-2011.pdf

Australian Swimming Coaches and Teachers Association (ASCTA). (2013). Swim Australia Teacher (SAT) course evaluations summary. Beerwah, QLD: Author.

Department of Education. (2013). Physical education programmes of study: Key stages 1 and 2. National curriculum in England. Retrieved from https://www. gov.uk/government/uploads/system/uploads/attachment_data/ file/239040/PRIMARY_national_curriculum_-_Physical_education.pdf 
Douglas, R. (2013, October 9). It's good to be king: How social status affects health. The Conversation. Retrieved from http://theconversation.com/itsgood-to-be-king-how-social-status-affects-health 18296 ? utm medium=email\&utm_campaign=Latest + from + The + Conversation + for $+9+$ Oct ober+2013\&utm_content $=$ Latest + from + The + Conversation + for $+9+$ October + $2013+$ CID_62f923lbfb3bdb4acc5cblb60c7a2ce5\&utm_source=campaign_ monitor\&utm_term $=$ Its $\% 20$ good $\% 20$ to $\% 20$ be $\% 20$ king $\% 20$ how $\% 20$ social $\% 20$ status\%20affects\%20health

Ewing, R. (2010). Curriculum and assessment: A narrative approach. South Melbourne, VIC: Oxford University Press.

Kirk, D. (2005). Physical education, youth sport and lifelong participation: The importance of early learning experiences. European Physical Education Review, $11(3), 239-255$.

Larsen, P. (2013, March 6). Royal Life Saving pushes for compulsory swimming and water safety. Retrieved from http://www.achper.org.au/blog/blog-royallife-saving-pushes-for-compulsory-swimming-water-safety

Lynch, T. (2013, November 27-29). Swimming and water safety education: continuing the journey of belief. Paper presented at the 28th Australian Council for Health, Physical Education and Recreation (ACHPER) International Conference, Melbourne (Australia).

Lynch, T. (2015). Australian aquatic curriculum reform: Treading water carefully. International Journal of Aquatic Research and Education, 9(2), 201-213. doi:10.1123/ijare.2015-0005\#_blank.

Ministerial Council on Education, Employment, Training and Youth Affairs. (2008). Melbourne declaration on education goals for young Australians. Retrieved from http://www.curriculum.edu.au/verve/_resources/National_ Declaration_on_the_Educational_Goals_for_Young_Australians.pdf

Monash University Faculty of Education. (2013a). EDF2611 experiencing aquatic environments unit evaluation report. Retrieved from http://emuapps.monash. edu.au/unitevaluations/wr/uewr_rpl_public.jsp?semester $=1$ \&year $=2013$ \&report_scope $=U \&$ faculty_cd $=50000564 \&$ unit_cd=EDF261 1 \&ref_unit_ cd=no_ref_cd

Monash University Faculty of Education. (2013b). EDF2611 experiencing aquatic environments Gippsland student evaluations of teaching unit (SETU) semester one qualitative data. Melbourne, VIC: Author.

Paton, G. (2014, November 5). Half of primary school children cannot swim 25 meters. The Telegraph. Retrieved from http://www.telegraph.co.uk/education/educationnews/11208255/Half-of-primary-school-children-cannotswim-25-meters.html

Peden, A., Franklin, R., \& Larsen, P. (2009). Survey of primary schools across Australia: An examination of key water safety issues. International Journal of Aquatic Research and Education, 2009(3), 197-208. 
Queensland School Curriculum Council. (1999). Health and physical education initial in-service materials. Brisbane, QLD: Publishing Services, Educational Queensland.

Royal Life Saving Society Australia. (2010). The national drowning report 2010. Canberra, ACT: RLSSA.

Russell, B. (2000, July 21). Schools fail to teach children to swim. Independent. Retrieved from http://www.independent.co.uk/news/education/educationnews/schools-fail-to-teach-children-to-swim-5369569.html

Symons, R. (2013, June 10). Partnering up in the pool. Latrobe Valley Express, 3.

Thompson, A. (2012, December 19). Principal seeks state-funded swim lessons after poor parents pull children from classes. Herald Sun. Retrieved from http://www.heraldsun.com.au/news/victoria/principal-seeks-state-fundedswim-lessons-after-poor-parents-pull-children-from-classes/story-e $6 \mathrm{frf7kx}$ 1226539935638 